\title{
Assessment of the effects of the dry period on the faunal composition of aquatic macroinvertebrate assemblages in two temporary ponds in NW Spain
}

\author{
Amaia PÉREZ-BILBAO, ${ }^{*}$ Cesar J. BENETTI, Josefina GARRIDO \\ Department of Ecology and Animal Biology, Faculty of Biology, University of Vigo, 36310 Vigo, Spain \\ * Corresponding author: amaiapb@uvigo.es
}

\begin{abstract}
Temporary ponds are habitats that undergo periods of drying and flooding. They have been neglected for many years and changes produced by climatic change will greatly affect them. Thus, nowadays they constitute an endangered ecosystem due to their characteristics and to human pressures. These habitats support a high biological richness with species adapted to extreme conditions. Assuming that hydroperiod is the main factor structuring aquatic assemblages in this type of ecosystem, the aim of this study was to assess the effect of the dry period on the faunal composition and the natural succession process of macroinvertebrate assemblages in two temporary ponds and to analyze the differences between two periods, before and after the dry period. A total of 7225 individuals belonging to 93 macroinvertebrate taxa (Nematoda, Hirudinea, Oligochaeta, Mollusca, Crustacea, Acari, Insecta) were collected. The most abundant and richest group were insects. Cluster and Non-Metric Multi-Dimensional Scaling (NMDS) analyses showed the clustering of the samples in two groups, before and after the dry period, as we had expected. Thus, there was a change in faunal composition in both ponds, corresponding to a successional process. According to the SIMPER analysis, the most contributive taxa in both ponds were mostly insects and crustaceans. Regarding feeding traits, predators and shredders were the dominant groups. However, there was a change in the trophic structure of the assemblages between the two periods. Most taxa resist the drying season with resting eggs, cocoons or simply by flying to more permanent freshwater bodies. Although the two studied ponds are temporary habitats, they support a different faunal composition hosting species that are endemic or rare at regional or national level.
\end{abstract}

Key words: Temporary ponds, dry period, succession, macroinvertebrates, traits, NW Spain.

Received: July 2014. Accepted: February 2015.

\section{INTRODUCTION}

Temporary ponds are habitats with a predictable annual dry phase of 3-8 months, usually during summer and autumn (Ward, 1992). According to Williams (1997), temporary ponds can be classified as intermittent (with a seasonal cyclic pattern of dryness and flooding) or episodic (unpredictably flooded). Due to their small size and shallowness these ecosystems are endangered (Collinson et al., 1995). Small changes in hydrological regimes can greatly impact the ecological regime of temporary ponds (Zacharias et al., 2007) and it is expected that the reduction of rainfall due to climate change will affect their hydrology (Williams et al., 1998). Temporary ponds have been neglected for years and nowadays are seriously affected by human activities such as agriculture, urbanization, etc. The inclusion of Mediterranean temporary ponds (3170) as a priority habitat for conservation in the Habitats Directive (European Commission, 1992) highlighted the importance of these ecosystems and the need to conserve them.

According to Boix et al. (2001, 2004), hydroperiod is one of the main factors affecting the composition and structure of aquatic assemblages. Temporary ponds support biological communities different to those that inhabit permanent ones. Although these ecosystems usually support lower species richness than permanent ones, several studies have demonstrated the importance of temporary ponds for rare and endangered invertebrate species (Collinson et al., 1995; Standen, 1999; Della Bella et al., 2005).

During the hydroperiod, the faunal composition goes through different phases of succession. The successional patterns in temporary aquatic environments have been dealt in different papers (Williams, 1983; Lake et al., 1989; Lahr et al., 1999; Bazzanti et al., 1996; Boix et al., 2004; Culioli et al., 2006). Besides, studies based on a taxonomic approach show the temporal changes of the assemblages related to the different life-history strategies of the organisms, such as dispersion or resistance to dry periods (Wiggins et al., 1980).

Organisms that live in temporary waters are adapted to survive under temporary drought conditions, sometimes being exclusive to these ecosystems (Williams, 2006). They have developed morphological adaptations, life cycles and dispersion mechanisms which make them survive in dry seasons. Invertebrates of temporary ponds usually exhibit traits of $r$-selected species, especially great dispersal ability, rapid growth, short life-span, small size, and opportunistic/generalistic feeding (Williams, 1997). 
Based on the four groups proposed by Wiggins et al. (1980), aquatic organisms have two strategies to survive dry periods: to pass the dry phase via resistant life stages or to actively migrate when water disappears. Among the invertebrates living in temporary ponds, the richest and most abundant groups are insects and crustaceans (Boix et al., 2001). Insects are characterized by active dispersion, while crustaceans and other groups such as snails or annelids can be considered passive dispersers.

In Spain, studies focused on temporary ponds have been mainly carried out in the Mediterranean region (Boix et al., 2001, 2004; Fernández et al., 2009; Florencio et al., 2009, 2012; Díaz-Paniagua et al., 2010; Garmendia and Pedrola-Monfort, 2010). In Galicia (NW Spain) there are no studies dealing with the biology and ecology of temporary ponds. Thus, this work constitutes the first attempt to explain the effect of natural drought on aquatic invertebrate fauna in this region.

The present paper deals with the faunistic succession of macroinvertebrate assemblages in temporary ponds. The aims of this study were to assess the effect of dry pe- riod on the faunal composition of the studied fauna and to analyse the differences between two periods, before and after the dry phase.

\section{METHODS}

\section{Study area}

Two temporary ponds classified as intermittent waters according to Williams (1997) were studied: Sacra de Olives and $A$ Veiga da Pencha. Both of them are protected under the Natura 2000 network. These ponds are located in the Autonomous Community of Galicia (North-Western Spain) (Fig. 1). The climate in this region is warm temperate, with dry summers and mild temperature (Kottek et al., 2006). This territory belongs to the Atlantic and Mediterranean biogeographical regions, with a total area of $29,574 \mathrm{~km}^{2}$ and more than $1200 \mathrm{~km}$ of coastline distributed between the Atlantic Ocean and the Cantabrian Sea. Altitude ranges from the coast to more than $2000 \mathrm{~m}$ in the mountains.

A Veiga da Pencha (VP) is a Mediterranean pond of

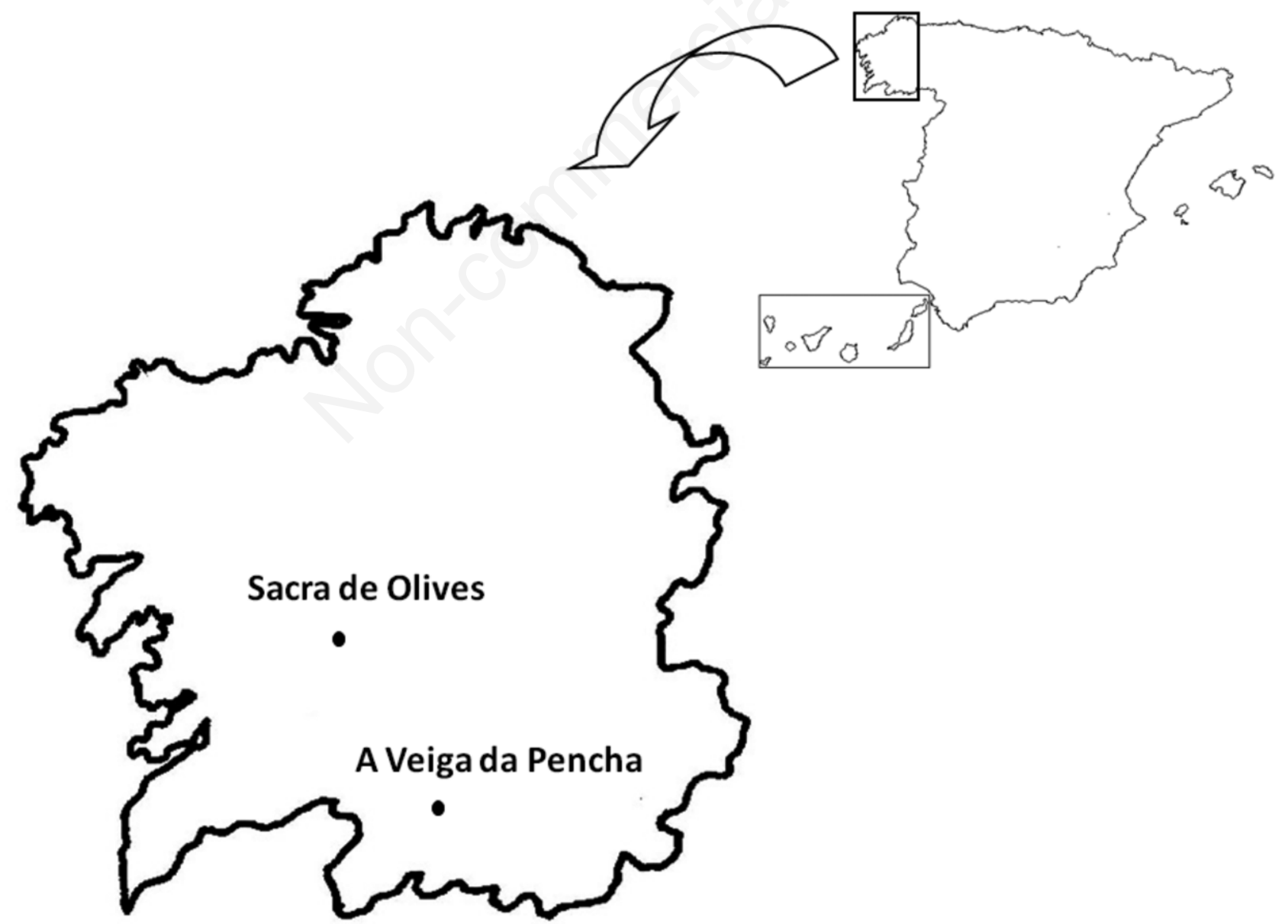

Fig.1. Map of Galicia (North-western Spain) showing the location of the sampled wetlands. 
0.25 ha located in the Limia River valley in the south of Galicia at $625 \mathrm{~m}$ altitude. It is included in the Special Area of Conservation (SAC) Veiga de Ponteliñares and the Biosphere Reserve Área de Allariz. This SAC is a floodplain area located just in the banks of the Limia River and surrounded by medium altitude mountains. Deciduous trees and grasses constitute the main riparian vegetation of the studied pond. The land uses around the pond are cattle farming, crops and small farms. During the surveys we confirmed the presence of only one fish species, the stickleback Gasterosteus aculeatus (Linnaeus), which feeds on insects, small crustaceans and fish larvae.

The Sacra de Olives (SO) pond is located in the middle of Galicia at $678 \mathrm{~m}$ altitude and belongs to the Atlantic Region. It is included in the SAC Brañas de Xestoso and it has a surface of $1.06 \mathrm{ha}$. The landscape is dominated by bushes and the land uses are mainly cattle farming and crops. During the surveys no fish species were captured. The pond is more isolated than VP and there are no large watercourses in the surroundings.

\section{Sampling}

The survey was carried out monthly during a year, from April 2010 to March 2011. The two ponds dried between July and October, so they were sampled 8 times each. Thus, we sampled in two periods: after the dry phase, corresponding to the end of the hydroperiod (AprilJune 2010), and before the dry phase, corresponding to the beginning of the next hydroperiod (November 2010March 2011). The dry period (July-October 2010) can be considered as normal, because these ponds usually remain dry three or four months every summer. Aquatic macroinvertebrates were collected using an entomological net (500 $\mu \mathrm{m}$ mesh, $30 \mathrm{~cm}$ diameter and $60 \mathrm{~cm}$ deep). Sampling was time-limited. Three minutes total sampling time for each wetland was split equally between different meso-habitat types (Biggs et al., 1998). The material was preserved in $99 \%$ ethanol, and sorted out and identified at the laboratory. Macroinvertebrates were identified to the lowest possible taxonomic level, mostly to species or genus level. All individuals are deposited in the collection of the Aquatic Entomology Lab of the University of Vigo.

\section{Data analysis}

To achieve the aims, we analysed changes in faunal composition related to taxa, functional feeding groups and survival strategies.

Macroinvertebrates were classified into different functional feeding groups according to the literature (Merritt and Cummins, 1996; Nilsson, 1996, 1997; Tachet et al., 2002). Organisms were also classified based on the biological trait of the resistance form according to Tachet $e t$ al. (2002) in order to know which strategies they follow to survive dry periods in the studied ponds: i) resting eggs; ii) cocoons; iii) building refugia; iv) diapause; v) none. For statistical analyses, biotic data were transformed via square root transformation to reduce the weight of very abundant species. Analyses were carried out on global abundances of macroinvertebrate taxa using the statistical package PRIMER (ver. 6, PRIMER-E Ltd). Similarity relationships among aquatic macroinvertebrate assemblages in all samples of each pond were determined by the BrayCurtis coefficient. Similar groups in terms of aquatic macroinvertebrate composition were identified by Cluster analysis (group average mode) and graphically presented using Non-metric Multi-Dimensional Scaling (NMDS) mapped in two dimensions. Analysis of similarity (ANOSIM) was used to test whether the established groups based on biotic data differed significantly.

To investigate the groups' consistency the SIMilarity PERcentages-species contributions (SIMPER) analysis was used to obtain differences between all pairs of groups and the contribution of each species for the groups in the two ponds. SIMPER examines the contribution of each species to the average Bray-Curtis dissimilarity between groups of samples and also determines the contribution to similarity within a group (Clarke and Warwick, 2001). This analysis would help us to know which taxa were dominant before and after the dry period in each pond.

\section{RESULTS}

A total of 7225 individuals belonging to 93 macroinvertebrate taxa were collected. In VP 78 taxa were captured during the study, while in SO 37 taxa were captured. In general, the most representative and abundant group was insects (27 taxa), especially Coleoptera (8 families), and Odonata, Hemiptera and Diptera (5 families). Regarding the other faunal groups, four families of Oligochaeta, three Crustacea, three Hirudinea, three Mollusca, one Nematoda and one Acari were recorded (Tab. 1). According to the biological traits, most of the taxa resist the dry season with resting eggs (e.g., Lepidurus apus (L.), Tanymastix stagnalis Daday), cocoons (e.g., Oligochaeta) or no resistance strategy (e.g., most Coleoptera species). Changes before and after the dry period in VP were not significant. On the contrary, in SO before the dry phase almost all of the taxa presented no resistance strategy, while after the dry period, taxa with other strategies (resting eggs, cocoons) were captured (Fig. 2). Considering the functional feeding groups, predators (44\%) and shredders $(18 \%)$ were the dominant groups in both ponds. In $\mathrm{SO}$, after the dry period predators, shredders and scrapers decreased, gatherers increased, and filterers and piercers appeared. The same occurred in VP, with the exception of predators. Although this group presented a lower number of taxa after the dry phase than before, its percentage increased proportionally (Fig. 3). 
Tab. 1. List of the taxa collected in both ponds before and after the dry period.

\begin{tabular}{|c|c|c|c|c|c|c|c|c|c|}
\hline & & & V & & & & & V & \\
\hline & Before & After & Before & After & & Before & After & Before & After \\
\hline HIRUDINEA & & & & & Dytiscidae & & & & \\
\hline Erpobdellidae & & & & & Liopterus atriceps & & & 13 & \\
\hline Erpobdella sp. & & & 62 & 1 & Laccophilus minutus & & & 6 & \\
\hline Haemopidae & & & & & Hydrovatus clypealis & & & 27 & \\
\hline Haemopis sanguisuga & & & 2 & & Bidessus goudoti & & & 13 & \\
\hline Glossiphoniidae & & & & & Hydroglyphus geminus & 1 & & & \\
\hline Glossiphonia sp. & & & & 1 & Hygrotus inaequalis & & & 15 & \\
\hline NEMATODA & & & 1 & & Hydroporus gyllenhali & 3 & & 3 & \\
\hline MOLLUSCA & & & & & Hydroporus vespertinus & 40 & 10 & 1 & 20 \\
\hline Lymnaeidae & & & & & Graptodytes bilineatus & & & & 3 \\
\hline Radix sp. & & & 38 & 21 & Graptodytes castilianus & & & & 1 \\
\hline Planorbidae & & & & & Graptodytes flavipes & & & 4 & \\
\hline Gyraulus sp. & & & 8 & 13 & Graptodytes fractus & & & & 1 \\
\hline Sphaeriidae & & & & & Agabus bipustulatus & 2 & & 9 & \\
\hline Pisidium sp. & & & 38 & 20 & Agabus labiatus & 1 & 2 & & \\
\hline Sphaerium sp. & & & 314 & 12 & Agabus nebulosus & 1 & & & \\
\hline OLIGOCHAETA & & & & & Ilybius dettneri & & & 1 & \\
\hline Lumbricidae & & 20 & 20 & 61 & Rhantus (Rhantus) hispanicus & & & & 1 \\
\hline Enchytraeidae & & & & 17 & Colymbetes fuscus & & & 8 & \\
\hline Naididae & & & 41 & 3 & Dytiscus semisulcatus & 1 & & & \\
\hline Stylaria lacustris & & & 8 & 246 & Helophoridae & & & & \\
\hline Tubificidae & & 6 & 28 & 51 & Helophorus (Trichohelophorus) alternans & 11 & & & \\
\hline CRUSTACEA & & & & & Helophorus (Rhopalohelophorus) bameuli & & & 2 & \\
\hline Branchipodidae & & & & & Helophorus (Rhopalohelophorus) flavipes & 593 & 3 & 5 & \\
\hline Tanymastix stagnalis & & 163 & & & Helophorus (Rhopalohelophorus) lapponicus & $s 12$ & & & \\
\hline Triopsidae & & & & & Helophorus (Rhopalohelophorus) minutus & & 1 & 1 & \\
\hline Lepidurus apus & & & 1 & & Hydrochidae & & & & \\
\hline Asellidae & & & 169 & 3 & Hydrochus angustatus & & & 5 & \\
\hline ACARI & 1 & 32 & 128 & 95 & Hydrcohus flavipennis & 1 & & & \\
\hline INSECTA & & & & & Hydrochus nitidicollis & & & 1 & \\
\hline Lestidae & & & & & Hydrophilidae & & & & \\
\hline Lestes dryas & & & 568 & 3 & Berosus (Berosus) affinis & & & & 1 \\
\hline Lestes viridis & & & 3 & & Berosus (Berosus) signaticollis & 12 & 15 & 6 & \\
\hline Coenagrionidae & 1 & & & & Paracymus scutellaris & 1 & & 72 & \\
\hline Pyrrhosoma nymphula & & & & 1 & Anacaena (Anacaena) lutescens & & & 141 & \\
\hline Aeshnidae & 1 & & & & Laccobius (Dimorpholaccobius) atratus & 3 & & & \\
\hline Aeshna mixta & & & 17 & 7 & Helochares (Helochares) punctatus & & & 22 & \\
\hline Corduliidae & & & & 5 & Enochrus (Lumetus) fuscipennis & 57 & & 17 & \\
\hline Libellulidae & & & & & Enochrus (Methydrus) nigritus & 1 & & 158 & \\
\hline Sympetrum sanguineum & & & 37 & & Hydrobius fuscipes & & & 124 & \\
\hline Baetidae & & & & & Limnoxenus niger & & & 2 & \\
\hline Procloeon sp. & & & 20 & 1 & Hydraenidae & & & & \\
\hline Siphlonuridae & & & & & Hydraena rugosa & & & 1 & \\
\hline Siphlonurus sp. & & & 2 & 26 & Elmidae & & & & \\
\hline Nemouridae & & & & & Oulimnius bertrandi & & & 2 & \\
\hline Nemoura sp. & & 1 & & 1 & Oulimnius rivularis & & & & 5 \\
\hline Gerridae & & & & & Dryopidae & & & & \\
\hline Gerris (Gerris) thoracicus & 1 & & & 2 & Dryops luridus & & & 1 & \\
\hline Notonectidae & & & & & Dryops striatellus & 278 & 205 & & \\
\hline Notonecta glauca glauca & 1 & & & 1 & Culicidae & & & & \\
\hline Notonecta maculata & 2 & & & & Culicinae & & & & 1 \\
\hline Notonecta meridionalis & & & & 2 & Anophelinae & & & & \\
\hline Notonecta obliqua & 6 & & & 1 & Anopheles sp. & & & 85 & \\
\hline Pleidae & & & & & Ceratopogonidae & & & & \\
\hline Plea minutissima & & & 3 & & Ceratopogoninae & & & 26 & 82 \\
\hline Nepidae & & & & & Chironomidae & & & & \\
\hline Nepa cinerea & & & 1 & 1 & Tanypodinae & & & 330 & \\
\hline Corixidae & & & & & Orthocladiinae & 8 & 1079 & 96 & 110 \\
\hline Corixa iberica & & & & 2 & Chironomini & & & 157 & 199 \\
\hline Corixa punctata & 13 & & & & Tanytarsini & & & 5 & 11 \\
\hline Hesperocorixa sahlbergi & 50 & 20 & 59 & 162 & Rhagionidae & & 2 & & \\
\hline $\begin{array}{l}\text { Sigara (Retrocorixa) limitata } \\
\text { Sigara (Sigara) janssoni }\end{array}$ & & & & $\begin{array}{c}5 \\
71\end{array}$ & Empididae & & & & \\
\hline Sigara (Vermicorixa) lateralis & & 1 & & 71 & $\begin{array}{l}\text { Hemerodromiinae } \\
\text { Limnephilidae }\end{array}$ & & & 2 & \\
\hline Haliplidae & & $?$ & 1 & $?$ & Limnephilus sp. & 1 & 2 & 227 & 115 \\
\hline Haliplus (Haliplus) heydeni & & & 6 & 8 & $O$, Sacra de Olives; $V P$, A Veiga da Pencha. & & & & \\
\hline
\end{tabular}


Two groups were found in both ponds based on the Cluster analyses (Fig. 4), which showed the clear separation of the samples before and after the dry period. The NMDS ordination shows the spatial distribution of all samples and grouping according to faunal similarity (Fig. 5). The stress obtained with the ordination was $<0.05$, which ensures good consistency of results. According to the ANOSIM, the established groups (before and after dry period) were significantly different to each other in both ponds (VP, Global test: $\mathrm{R}=0.93, \mathrm{P}=0.018,999$ permutations; $\mathrm{SO}$, Global test: $\mathrm{R}=0.6, \mathrm{P}=0.018,999$ permutations).

The contribution of the taxa to each group of each pond according to the SIMPER analysis is given in Tab. 2. In VP, similarity within groups ranged from $36.53 \%$ (before) to $46.26 \%$ (after) and the mean dissimilarity between groups was $73.40 \%$. Many faunal groups contributed to group similarity before and after the dry period, especially crustaceans (Asellidae) and several insect taxa (Odonata, Trichoptera, Diptera, Hemiptera). In SO, the similarity within groups ranged from $37.41 \%$ (before) to $44.26 \%$ (after) and the mean dissimilarity between groups was

a

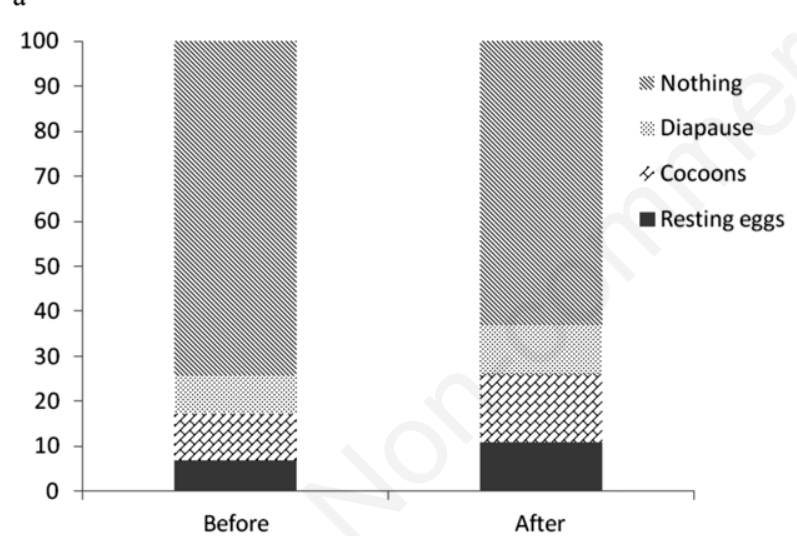

b

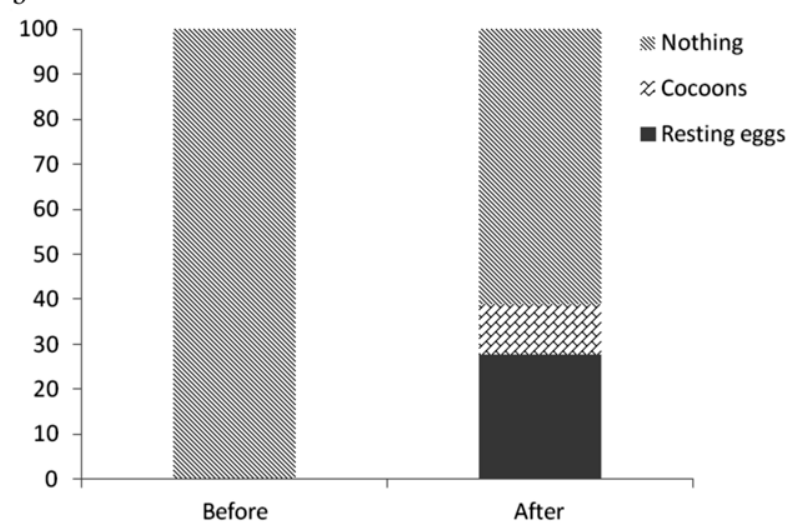

Fig. 2. Percentages of the different biological traits of resistance forms to the dry period in the A Veiga da Pencha (a) and Sacra de Olives (b) ponds.
$72.18 \%$. The faunal groups that most contributed to group similarity before the dry period were beetles and bugs, while after the dry period they were mainly insects (Diptera, Coleoptera), mites and crustaceans (T. stagnalis).

Some faunal groups were more abundant before the dry phase and others in the first months after it. After, 25 species of aquatic Coleoptera disappeared from VP, and only three taxa were collected during the whole wet period of the pond (Orthocladiinae, Hesperocorixa sahlbergi (Fieber) and Limnephilus sp.). On the other hand, no crustaceans were collected in SO before the dry period, but the branchiopod Tanymastix stagnalis (Linnaeus) was relatively abundant after the dry season. This species colonized the pond in the first phases of the filling and after they disappeared. Hemiptera almost disappeared after the dry period. The only taxon present during the whole wet phase of the pond was the beetle Dryops striatellus (Fairmaire \& Brisout). Both ponds presented several exclusive taxa that were not found in the other pond. Mollusca, Platyhelminthes, Odonata, Culicidae, L. apus, Stylaria la-

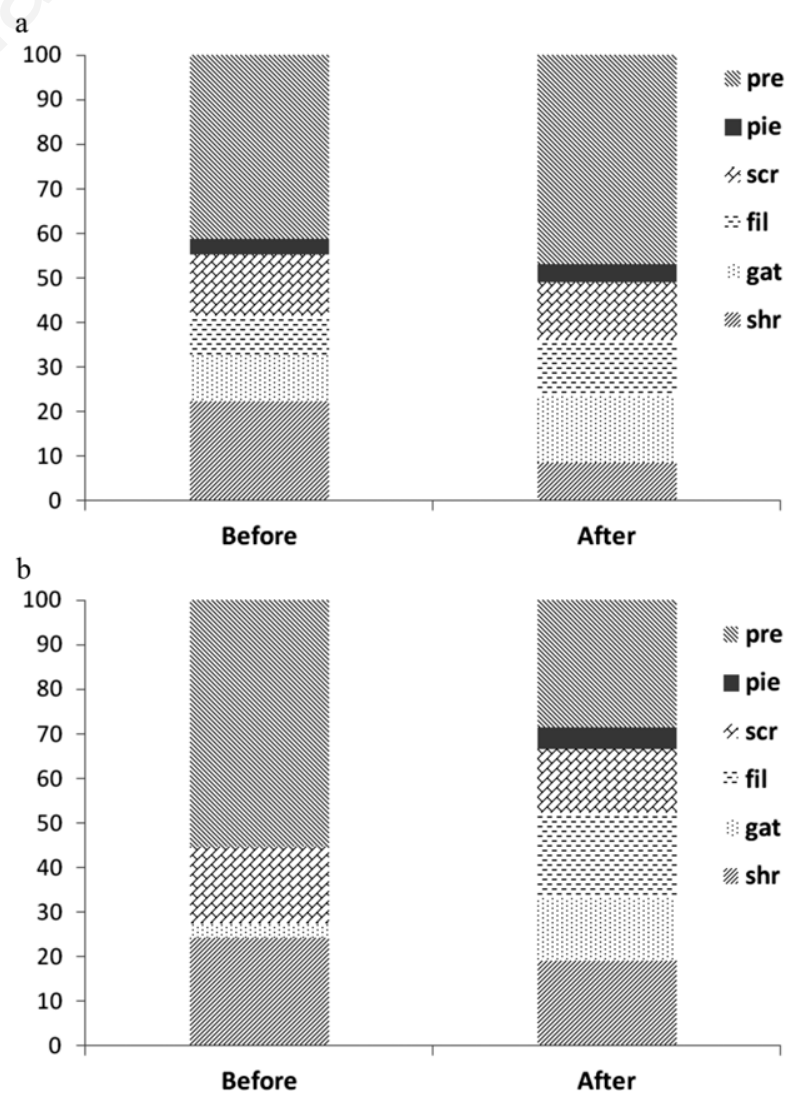

Fig. 3. Percentages of the different functional feeding groups before and after the dry period in the A Veiga da Pencha (a) and Sacra de Olives (b) ponds. pre, predators; pie, piercers; scr, scrappers; fil, filterers; gat, gatherers; shr, shredders. 
custris (L.) and several Coleoptera and Hemiptera species were only found in VP, while Nematoda, T. stagnalis and some Coleoptera and Hemiptera species were only collected in $\mathrm{SO}$.

\section{DISCUSSION}

The statistical analyses showed significant differences in both ponds between the two periods (before and after the dry period). This means that the assemblages change and the faunal composition is not the same after the dry period, representing a succession process. Some species were not found after the dry period in either pond, although they were very abundant in the samplings before the drying season. The lack of species with great dispersal ability (e.g., Coleoptera or Hemiptera) could be due to randomness. These species leave the unfavourable habitat searching for better conditions, but this does not mean they are going to return to the same water body when conditions improve. Normal succession process can explain changes in faunal composition in the studied ponds. The results obtained in this study are according to other described for temporary ponds in Mediterranean regions (Boix et al., 2004; Culioli et al., 2006), specially related to dominant groups and functional traits.

According to the SIMPER analysis, in VP the most contributive taxa were mostly insects and crustaceans. Before the dry phase, Asellidae were the most predominant whereas after it, H. sahlbergi was. In SO the most contributive groups before the dry period were Coleoptera and Hemiptera, while after it, they were mostly dipterans (Orthocladiinae) and coleopterans (D. striatellus). This is an expected result since these groups (insects and crustaceans) are the largest ones in this type of habitat (Boix et al., 2001) and confirms the differences in the assemblage composition between the two periods.

In general, both ponds showed a high abundance of passively dispersing groups like molluscs and oligochaetes. This result agrees with Porst et al. (2012),

a

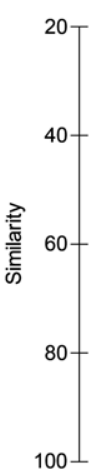

Group average

Transform: Square root

Resemblance: S17 Bray Curtis similarity
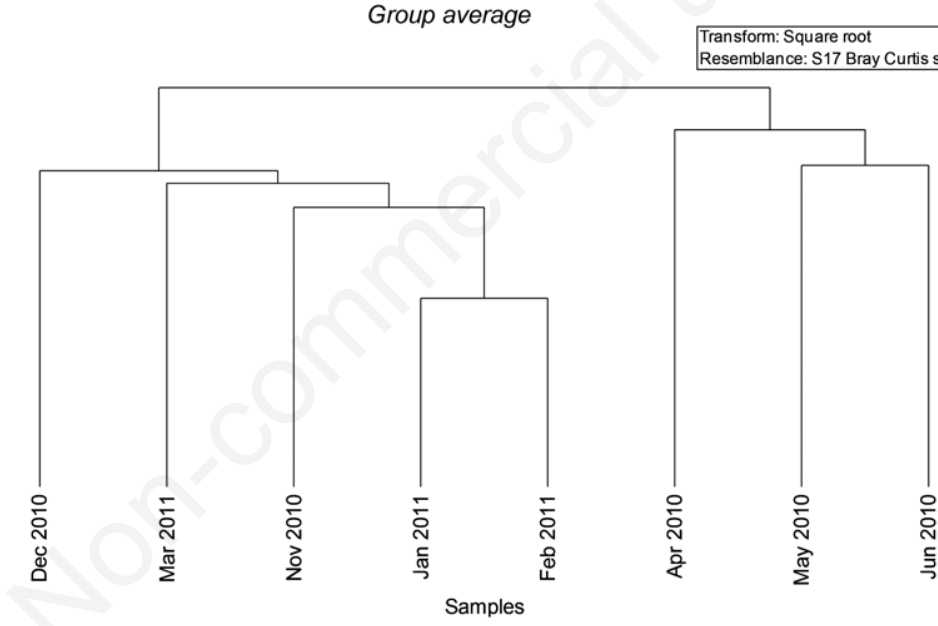

b

Group average
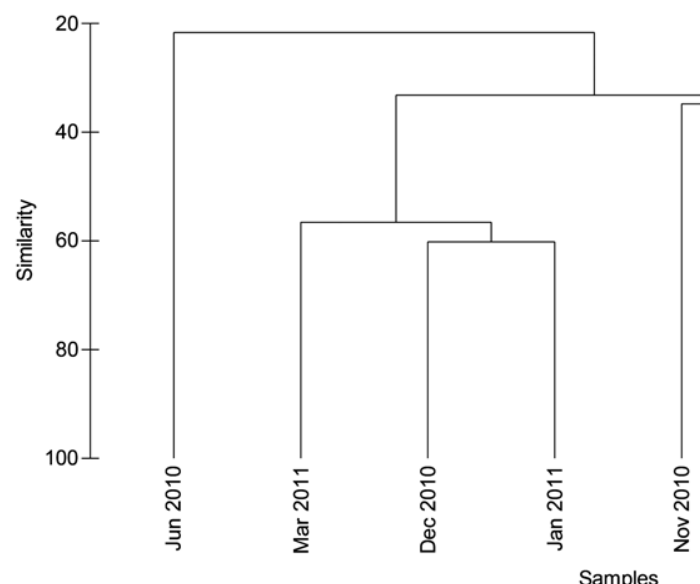

Transform: Square root Resemblance: S17 Bray Curtis similarity

Fig. 4. Clustering of the samples in both ponds in the A Veiga da Pencha (a) and Sacra de Olives (b) ponds. 
who found the same in Irish turloughs. According to Vanschoenwinkel et al. (2009), passive dispersers are more affected by the hydroperiod than active ones due to their low dispersal ability, which makes them, in general, permanent inhabitants of temporary ponds. In contrast, some groups, like Coleoptera, Hemiptera, Ephemeroptera and most Chironomidae, are considered cyclic colonizers that inhabit temporary habitats during the wet phase and migrate to permanent systems to avoid dry conditions (Williams, 1987). Regarding feeding traits, predators and shredders were the dominant groups. This result agrees with those obtained by Culioli et al. (2006) in a temporary pond in Corsica. However, there was a change in the trophic organization of both ponds. Before the dry period the assemblages were dominated by predators and shredders, and after the dry period these groups diminished and gatherers and filterers increased in number. Culioli et al. (2006) also found a negative correlation between shredders and flooding (filling phase), but contrary to our results, they obtained a positive correlation between predators and flooding. Feeding strategies reflect the adaptation of organisms to the habitat (Statzner et al., 2001). According to Barbour et al. (1999), in stress conditions there is an imbalance between trophic groups, the specialist groups being more sensitive to changes in food availability. Besides, the length of hydroperiod is among the main stressors in temporary freshwater ecosystems (Waterkeyn et al., 2008), so a change in the trophic structure is expected.

The dominant group in the studied ponds were insects. Among them, Coleoptera and Hemiptera were the dominant groups, along with Chironomidae (Orthocladiinae). These results agree with other studies in temporary ponds (Eyre et al., 1992; Boix et al., 2001; Nicolet et al., 2004; Bilton et al., 2009). Dytiscidae and Hydrophilidae were the most diverse water beetle families. Both of them are considered typical of stagnant waters (Ribera et al., 2003) and present great dispersal ability due to the instability of these ecosystems (Ribera and Vogler, 2000). Helophoridae were also important in SO, especially the species Helophorus flavipes Fabricius. Species in this family are commonly found in temporary habitats (Bilton et al., 2009; Porst et al., 2012; Pérez-Bilbao et al., 2014). On the other hand, Corixidae and Notonectidae were the most diverse Hemiptera families. As in the case of the mentioned water beetle families, these hemipterans are also common inhabitants of temporary ponds (Boix et al., 2001; Nicolet et al., 2004; Culioli et al., 2006; Florencio et al., 2009). Temporary ponds often host rare or unique species, some of them typical of these habitats, which highlights the importance of this type of ecosystem for the maintenance of biodiversity on a regional scale. Sev-

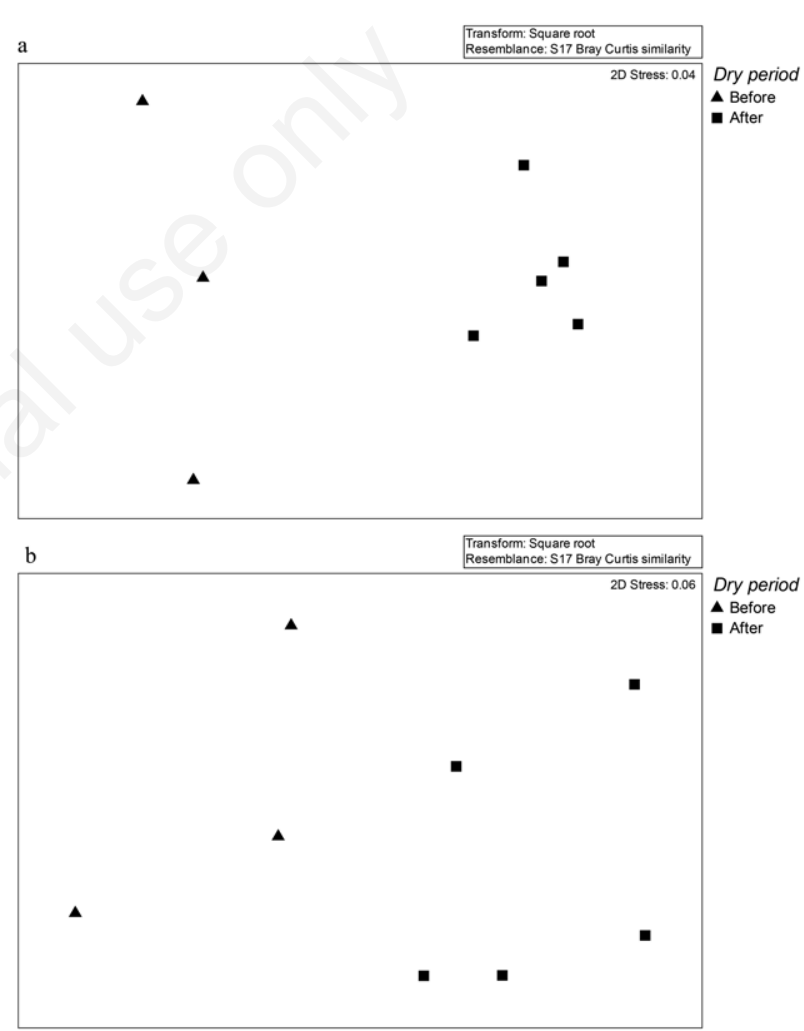

Fig. 5. Non-metric Multi-Dimensional Scaling (NMDS) analysis in the $A$ Veiga da Pencha (a) and Sacra de Olives (b) ponds.

Tab. 2. Taxa that most contributed to the characterization of each group according to the SIMPER analysis.

\begin{tabular}{|c|c|c|c|c|}
\hline Pond & Group & Samples no. & Most contributive taxa & Contribution to the group characterization \\
\hline \multirow[t]{2}{*}{ VP } & Before & 3 & $\begin{array}{l}\text { Asellidae, L. dryas, Limnephilus sp., S. sanguineum, } \\
\text { Othocladiinae, H. sahlbergi, H. clypealis }\end{array}$ & $53.45 \%$ (Asellidae contributed with $11.05 \%$ ) \\
\hline & After & 5 & $\begin{array}{l}\text { H. sahlbergi, Limnephilus sp., Chironomini, Acari, } \\
\text { S. lacustris, Orthocladiinae, Ceratopogoninae }\end{array}$ & $72.18 \%$ (H. sahlbergi contributed with $15.67 \%$ ) \\
\hline \multirow[t]{2}{*}{ SO } & Before & 3 & $\begin{array}{l}\text { D. striatellus, H. flavipes, E. fuscipennis, H. sahlbergi, } \\
\text { H. vespertinus, H. alternans }\end{array}$ & $93.34 \%$ (D. striatellus contributed with $46.83 \%$ ) \\
\hline & After & 5 & Orthocladiinae, D. striatellus, Acari, H. vespertinus, T. stagnalis & $91.13 \%$ (Orthocladiinae contributed with $48.30 \%$ ) \\
\hline
\end{tabular}

$S O$, Sacra de Olives; VP, A Veiga da Pencha. 
eral uncommon species were collected in SO. For example, Helophorus lapponicus (Thomson), Agabus labiatus (Brahm) and Hydroporus brancoi brancoi Rocchi, which are little cited in the Iberian Peninsula, while Sigara lateralis (Leach) is widely distributed in the Iberian Peninsula but rare in Galicia. The latter is considered a pioneer species that appears in the re-filling phase (Boix et al., 2001). Another pioneer species collected in SO was Berosus signaticollis (Charpentier), which remains embedded in the sediment to complete its life cycle (Boix et al., 2001), although in SO it was barely captured in the re-filling phase (from November onwards) and in VP it was not found after the dry period.

In VP we found a different assemblage composition to that observed in SO. In this pond two Odonata species typical of temporary habitats were recorded, Lestes dryas Kirby and Sympetrum sanguineum (Muller). These two species can complete their life cycles before the habitat dries out. Both of them appeared almost exclusively before the dry phase, $L$. dryas being very abundant. Porst $e t$ al. (2012) also found them in Irish turloughs before the drying season. Other species barely recorded in the Iberian Peninsula were collected in VP, such as Hesperocorixa moesta (Fieber), Sigara limitata (Fieber), A. labiatus, Liopterus atriceps Sharp or Graptodytes bilineatus (Sturm). Some of these species are Iberian endemics, like Sigara janssoni Lucas, Helophorus bameuli Angus or Graptodytes castilianus Fery. So, their presence in this temporary pond is especially interesting as its natural value is increased. The fact that the aquatic beetle Hydraena rugosa Mulsant was captured should be highlighted. This species is little cited in the Iberian Peninsula but when found it is usually collected in high abundance (Valladares et al., 2002). In this study, only one individual was captured, while it appeared in high abundance in previous surveys conducted in this area (Pérez-Bilbao et al., 2010).

Two interesting species of crustaceans were collected during the surveys, Tanymastix stagnalis and Lepidurus apus. T. stagnalis inhabits small temporary ponds with low mineralization and clear water. In this study, it was recorded in SO in November and December, and then disappeared. This agrees with other studies (Culioli et al., 2006), in which the species appears in the re-filling phase and then disappears. It is not very frequent in the Iberian Peninsula and it survives dry periods with resting eggs (Alonso, 1996). L. apus lives in small temporary waters, such as flooded roadsides and ditch widenings and backwaters, always with aquatic vegetation. According to Alonso (1996), it is typical of low mineralized, dystrophic and, in general, clear waters. This crustacean is a rare species in the Iberian Peninsula and in this study only one specimen was captured in VP in spring, although it was captured in abundance in a study conducted in different water bodies near the study area (Garrido and Gayoso, 2002).
It is also important to note that the two ponds showed a different pattern, both in terms of species richness and faunal composition and with different successional patterns. In general, VP presented higher richness values than SO. In this aspect, different reasons could explain the differences found. One of the most likely is the proximity of the VP to the Limia River and other temporary ponds, which facilitates the mobility of the taxa between water bodies. On the other hand, SO is an isolated pond, distant to other freshwater ecosystems, which makes colonization more difficult. Several authors have addressed the importance of connectivity between aquatic habitats for biodiversity conservation (Briers and Biggs, 2005; Van de Meutter et al., 2006; Florencio et al., 2009).

Regarding faunal composition, it should be noted that although the two ponds are temporary and show similar hydroperiod, they host different species, some of them endemic or rare at regional or national scale. This is an important issue to take into account when elaborating management measures to ensure the protection of all temporary habitat types.

\section{CONCLUSIONS}

We have to highlight that the discrimination of both effects (succession and dry period) could be only achieved comparing two complete hydroperiods, one before the dry phase (autumn 2009-early summer 2010) and one after it (autumn 2010-early summer 2011). However, we could not explain it, because the aim of the work was to study these ponds along one year, with an intermediate dry phase. Therefore, in future studies we recommend studying a complete hydroperiod, starting in the filling phase and ending in the dry phase.

\section{ACKNOWLEDGMENTS}

This study was supported by the Galician Government with the project Assessment of the effectiveness of the wetlands included in the Galician Natura 2000 network as priority conservation areas for invertebrates (09MDS 006310PR). We want to thank the useful comments of the two referees, which helped us to improve the manuscript.

\section{REFERENCES}

Alonso M, 1996. [Crustacea, Branchiopoda].[Book in Spanish]. In: Ramos et al. (eds.), Fauna Ibérica, vol. 7, Museo Nacional de Ciencias Naturales, CSIC, Madrid: 486 pp.

Barbour MT, Gerritsen J, Snyder BD, Stribling JB, 1999. Rapid bioassessment protocols for use in streams and wadeable rivers: periphyton, benthic macroinvertebrates and fish. US EPA, Office of Water, Washington: $197 \mathrm{pp}$.

Bazzanti M, Baldoni S, Seminara M, 1996. Invertebrate macrofauna of a temporary pond in Central Italy: composition, community parameters and temporal succession. Arch. Hydrobiol. 137:77-94. 
Biggs J, Fox G, Nicolet P, Walker D, Whitfield M, Williams P, 1998. A guide to the methods of the national pond survey. Pond Action, Oxford: $22 \mathrm{pp}$.

Bilton DT, McAbendroth LC, Nicolet P, Bedford A, Rundle SD, Foggo A, Ramsay PM, 2009. Ecology and conservation status of temporary and fluctuating ponds in two areas of southern England. Aquat. Conserv. 19:134-146.

Boix D, Sala J, Moreno-Amichi R, 2001. The faunal composition of Espolla pond (NE Iberian Peninsula): the neglected biodiversity of temporary waters. Wetlands 21:577-592.

Boix D, Sala J, Quintana XD, Moreno-Amichi R, 2004. Succession of the animal community in a Mediterranean temporary pond. J. N. Am. Benthol. Soc. 23:29-49.

Briers RA, Biggs J, 2005. Spatial patterns in pond invertebrate communities: separating environmental and distance effects. Aquat. Conserv. 15:549-557.

Clarke KR, Warwick RM, 2001. Change in marine communities: an approach to statistical analysis and interpretation. Primere Ltd, Plymouth Marine Laboratory, Plymouth: 169 pp.

Collinson NH, Biggs J, Corfield A, Hodson MJ, Walker D, Whitfield M, Williams PJ, 1995. Temporary and permanent ponds: an assessment of the effects of drying out on the conservation value of aquatic macroinvertebrate communities. Biol. Cons. 74:125-133.

Culioli JL, Foata J, Mori C, Orsini A, Marchand B, 2006. Temporal succession of the macroinvertebrate fauna in a Corsican temporary pond. Vie Milieu 56:215-221.

Della Bella V, Bazzanti M, Chiarotti F, 2005. Macroinvertebrate diversity and conservation status of Mediterranean ponds in Italy: water permanence and mesohabitat influence. Aquat. Conserv. 15:583-600.

Díaz-Paniagua C, Fernández-Zamudio R, Florencio M, GarcíaMurillo P, Gómez-Rodríguez C, Portheault A, Serrano L, Siljeström P, 2010. Temporary ponds from Doñana National Park: a system of natural habitats for the preservation of aquatic flora and fauna. Limnetica 29:41-58.

Eyre MD, Carr R, McBlane RP, Foster GN, 1992. The effects of varying site-water duration on the distribution of water beetle assemblages, adults and larvae (Coleoptera: Haliplidae, Dytiscidae, Hydrophilidae). Arch. Hydrobiol. 124: 281-291.

Fernández AI, Viedma O, Sánchez-Carrillo S, Alvarez-Cobelas M, Angeler DG, 2009. Local and landscape effects on temporary pond zooplankton egg banks: conservation implications. Biodivers. Conserv. 18:2373-2386.

Florencio M, Díaz-Paniagua C, Gomez-Mestre I, Serrano L, 2012. Sampling macroinvertebrates in a temporary pond: comparing the suitability of two techniques to detect richness, spatial segregation and diel activity. Hydrobiologia 689:121-130.

Florencio M, Serrano L, Gómez-Rodríguez C, Millán A, DíazPaniagua C, 2009. Inter- and intra-annual variations of macroinvertebrate assemblages are related to the hydroperiod in Mediterranean temporary ponds. Hydrobiologia 634:167-183.

Garmendia A, Pedrola-Monfort J, 2010. Simulation model comparing the hydroperiod of temporary ponds with different shapes. Limnetica 29:145-152.

Garrido J, Gayoso A, 2002. [Primera cita de Lepidurus apus (Linnaeus, 1758) (Branchioposa: Notostraca) en Galicia
(NO España)].[Article in Spanish]. Boln. Asoc. esp. Ent. 26:197-198.

Kottek M, Grieser J, Beck C, Rudolf B, Rubel F, 2006. World map of the Köppen-Geiger climate classification updated. Meteorol. Z. 15:259-263.

Lake PS, Bayly IAE, Morton DW, 1989. The phenology of a temporary pond in western Victoria, Australia, with special reference to invertebrate succession. Arch. Hydrobiol. 115:171-202.

Lahr J, Diallo AO, Ndour KB, Badji A, Diouf PS, 1999. Phenology of invertebrates living in a sahelian temporary pond. Hydrobiologia 405:189-205.

Merritt RW, Cummins KW, 1996. An introduction to the aquatic insects of North America. Kendall/Hunt Publ. Co., Dubuque: $862 \mathrm{pp}$.

Nicolet P, Biggs J, Fox G, Hodson MJ, Reynolds C, Whitfield M, Williams P, 2004. The wetland plant and macroinvertebrate assemblages of temporary ponds in England and Wales. Biol. Cons. 120:261-278.

Nilsson A, 1996. Aquatic insects of North Europe. A Taxonomic Handbook. Ephemeroptera, Plecoptera, Heteroptera, Neuroptera, Megaloptera, Coleoptera, Trichoptera, Lepidoptera. Apollo Books, Stenstrup: 274 pp.

Nilsson A, 1997. Aquatic insects of North Europe. A Taxonomic Handbook. Odonata, Diptera. Apollo Books, Stenstrup: $440 \mathrm{pp}$.

Pérez-Bilbao A, Benetti CJ, Garrido J, 2010. [Nuevos datos sobre la familia Hydraenidae (Insecta, Coleoptera) en espacios protegidos de la Red Natura 2000 de Galicia (NO España)].[Article in Spanish]. Boln. Asoc. esp. Ent. 34:15-28.

Pérez-Bilbao A, Benetti CJ, Garrido J, 2014. Aquatic Coleoptera assemblages in protected wetlands of North-western Spain. J. Limnol. 73:81-91.

Porst G, Naughton O, Gill L, Johnston P, Irvine K, 2012. Adaptation, phenology and disturbance of macroinvertebrates in temporary water bodies. Hydrobiologia 696:47-62.

Ribera I, Vogler AP, 2000. Habitat type as a determinant of species range sizes: the example of lotic-lentic differences in aquatic Coleoptera. Biol. J. Linn. Soc. 71:33-52.

Ribera I, Foster GN, Vogler AP, 2003. Does habitat use explain large scale species richness patterns of aquatic beetles in Europe? Ecography 26:145-52.

Standen V, 1999. Quantifying macroinvertebrate taxon richness and abundance in open and forested pool complexes in the Sutherland flows. Aquat. Conserv. 9:209-217.

Statzner B, Hildrew AG, Resh VH, 2001. Species traits and environmental constraints: Entomological research and the history of ecological theory. Annu. Rev. Entomol. 46:291-316.

Tachet H, Richoux P, Bournaud M, Usseglio-Polatera P, 2002. Invertébrés d'eau douce: systématique, biologie, écologie. CNRS Editions, Paris: 587 pp.

Valladares LF, Garrido J, García-Criado F, 2002. The assemblages of aquatic Coleoptera from shallow lakes in the northern Iberian Meseta: Influence of environmental variables. Eur. J. Entomol. 99:289-298.

Van de Meutter F, Stoks R, de Meester L, 2006. Lotic dispersal of lentic macroinvertebrates. Ecography 29:223-230.

Vanschoenwinkel B, Hulsmans A, De Roeck E, De Vries C, Seaman M, Brendonck L, 2009. Community structure in temporary freshwater pools: disentangling the effects of habitat 
size and hydroregime. Freshwater Biol. 54:1487-1500.

Ward JV, 1992. Aquatic insect ecology, 1. Biology and habitat. John Wiley, New York: 438 pp.

Waterkeyn A, Grillas P, Vanschoenwinkel B, Brendonck L, 2008. Invertebrate community patterns in Mediterranean temporary wetlands along hydroperiod and salinity gradients. Freshwater Biol. 53:1808-1822.

Wiggins GB, Mackay RJ, Smith IM, 1980. Evolutionary and ecological strategies of animals in annual temporary pools. Arch. Hydrobiol. 58:97-206.

Williams DD, 1983. The natural history of a neartic temporary pond in Ontario with remarks on continental variation in such habitats. Intern. Revue Hydrobiol. Hydrogr. 68:239-253.

Williams DD, 1987. In: The Ecology of Temporary Waters.
Croom Helm. Timber Press Portland, London \& Sydney. Williams DD, 1997. Temporary ponds and their invertebrate communities. Aquatic Conserv. 7:105-117.

Williams DD, 2006. The biology of temporary waters. Oxford University Press, Oxford: 348 pp.

Williams PJ, Biggs J, Barr CJ, Cummins CP, Gillespie MK, Rich TCG, Baker A, Baker J, Beesley J, Corfield A, Dobson D, Culling AS, Fox G, Howard DC, Luursema K, Rich M, Samson D, Scott WA, White R, Whitfield M, 1998. Lowland Pond Survey 1996. Department of the Environment, Trade and the Regions, London.

Zacharias I, Dimitrou E, Dekker A, Dorsman E, 2007. Overview of temporary ponds in the Mediterranean region: threats, management and conservation issues. J. Environ. Biol. 28:1-9. 